\title{
Effect of precision land levelling and permanent raised bed planting on soil properties, input use efficiency, productivity and profitability under maize (Zea mays) - wheat (Triticum aestivum) cropping system
}

\author{
R. K. Naresh ${ }^{1}$, R. S. Rathore ${ }^{2}$, R. B. Yadav ${ }^{1}$, S. P. Singh ${ }^{3}$, A. K. Misra ${ }^{1}$, V. Kumar ${ }^{3}$, N. Kumar ${ }^{3}$ \\ and Raj K. Gupta \\ ${ }^{1}$ Department of Agronomy; Vallabhbhai Patel University of Agriculture and Technology, Meerut (U. P.), India. \\ ${ }^{2}$ D.D.G.Uttar Pradesh Council of Agricultural Research, Lucknow, India. \\ ${ }^{3}$ Department of Soil Science; Vallabhbhai Patel University of Agriculture and Technology, Meerut (U. P.), India. \\ ${ }^{4}$ K.V.K. Moradabad Sardar Vallabhbhai Patel University of Agriculture and Technology, Meerut (U. P.), India. \\ ${ }^{5}$ Research Station Developments, Borlaug Institute for South Asia, CIMMYT New Delhi, India.
}

Received 26 April, 2013; Accepted 15 May, 2014

\begin{abstract}
Precision land leveling with permanent raised bed planting with recommended dose of NPK can be used to improve crop yield, water and nutrient use efficiency over the existing traditional land leveling with flat beds planting with recommended dose of NPK practices. The objective of the present study was to establish an understanding of maize-wheat rotation yield and input use efficiency can be improved and how land leveling and crop establishment practices can be modified to be more efficient in water use through precision conservation crop management techniques. To conduct a farmers participatory field experiment during 2009-2011 in the jurisdiction of Sardar Vallabhbhai Patel University of Agriculture and Technology, Meerut, U.P. Multi crop planter with inclined plate seed metering device machine were given to the farmers and crops were sown on permanent raised beds in maize-wheat cropping system. The data collected from the farmers participatory field experiment showed that there was about $20.4 \%(295.8 \mathrm{~mm} / \mathrm{ha}$ for wide beds that is, $107 \mathrm{~cm}$ furrow centre gap) water saving and about $16.5 \%(310.3 \mathrm{~mm} / \mathrm{ha}$ for narrow beds that is, $37 \mathrm{~cm}$ furrow centre gap) with grain yield increase of about $13.5 \%$ (5.13 and $4.44 \mathrm{t} / \mathrm{ha}$ ) for wheat crop and $11.8 \%$ (4.33 and $3.82 \mathrm{t} / \mathrm{ha}$ ) for maize crop with precision land leveling raised bed planting compared to traditional land leveling with flat beds planting. The agronomic efficiency (AE) of N (23.4 and $30.4 \mathrm{~kg}$ grain $/ \mathrm{kg} \mathrm{N}$ for maize and wheat) and uptake of $\mathrm{N}, \mathrm{P}$ and $\mathrm{K}(103.85,25.6$ and $110.7 \mathrm{~kg} / \mathrm{ha}$ for maize and $112.95,19.49$ and $112.96 \mathrm{~kg} / \mathrm{ha}$ for wheat) were significantly improved under precision land leveling with raised bed planting technique compared to other practices.
\end{abstract}

Key words: Precision land leveling, productivity, profitibility, input use efficiency, permanent raised beds.

\section{INTRODUCTION}

Presently, $50 \%$ of the human population relies on nitrogen $(\mathrm{N})$ fertilizer for food production. The world today uses around 83 million metric tons of $\mathrm{N}$, which is about a 100-fold increase over the last 100 years (Ladha et al., 2013). About $60 \%$ of global $N$ fertilizer is used for producing the world's three major cereals: rice, wheat, 
and maize. Projections estimate that 50 to $70 \%$ more cereal grain will be required by 2050 to feed 9.3 billion people (Ladha et al., 2013). Stagnating yield and declining input use efficiency in irrigated maize-wheat of the Western Indo-Gangetic Plain (WIGP) coupled with diminishing availability of water for agriculture is a major concern of food security in South Asia. Achieving sustainable food security is a major challenge considering the growing population with changing diets and a degrading resource scenario. Maize or corn (Zea mays) is an important food and feed crop and is one of the most versatile, high yielding food crops of the world. In South Asia with limited availability of water, and aberration in temperature on account of climate change, it is becoming increasingly important that issues concerning it be addressed. Maize lends itself to various applications and has a high yield potential and wide adaptability across regions, seasons and altitudes, making it suited in different cropping and farming systems. Its demand is increasing on account of the shift towards animal based diets and expansion of the bio-fuel industry. Raised beds were introduced to rice- wheat systems of the Indo-Gangetic Plain (IGP) in the mid 1990s, initially for wheat, inspired by the success of irrigated maize-wheat on permanent raised beds (PRB) in Mexico (Sayre and Hobbs, 2004). Since then, many advantages of growing wheat on beds have been reported, including increased yields, reduced lodging, opportunities for mechanical weeding and improved fertiliser placement, irrigation water savings, reduced waterlogging, reduced seed rate and opportunities for intercropping (Ram et al., 2005; Naresh et al., 2011a). Around the same time that PRB were being proposed, an unprecedented revolution in adoption of 'zero-till' (directdrilled) wheat after rice was underway across the IGP (Malik et al., 2004). Majority of the

maize-wheat growers in the western Uttar Pradesh practice surface irrigation either through flood or check basin methods. The light textured soils under undulating topography leads to uneven distribution of water, which limits the availability of water and nutrients to the crop plants. Undulated crop fields when managed with flood irrigation, also lead to within field spatial variability in grain production owing to leaching of certain nutrients due to excess water at lower elevations and in-adequate availability of irrigated water at higher elevations. Naresh et al. (2011) reported that wheat and maize are planted in many parts of the world on beds and bed planting on an average saved $29 \%$ of water as compared to flat beds.

Land leveling is a precursor to good agronomic, soil and crop management practices and the levelness of the land surface has significant influence on all the farming operations. Jat et al. (2006) rated the development of laser technology for precision land leveling as second only to breeding of high yielding varieties. The soil moisture status throughout the field governed by its levelness has great influence not only on farming operations but also the yield and input use efficiency. The leveling of land for achieving higher resource use efficiency is not a new technique but the way in which it is done is not up to the mark as frequent patches of dikes and ditches stretched over a minimum workable distance are created even with best effort by conventional leveling practices. Undulated land hampers the seedbed preparation, seed placement, germination and also requires heavy draught for machines, which leads to consumption of more energy, and ultimately to more cost of production and low productivity levels. Improvement in operational efficiency, weed control efficiency, water use efficiency, nutrient use efficiency, crop productivity and economic returns (Naresh et al., 2014) and environmental benefits (Jat et al., 2006) been reported as a result of precision land leveling when compared to traditional practice of land leveling. The objective of this study was to evaluate the effect of precision land leveling and permanent raised beds planting on soil properties, input use efficiency, productivity and profitability under maize (Zea mays) - wheat (Triticum aestivum) cropping system on a sandy loam soil of western Uttar Pradesh.

\section{MATERIALS AND METHODS}

An experiment was conducted on maize-wheat rotation in three districts (Meerut, Ghaziabad and Saharanpur) in farmers participatory mode in the juridiction of Sardar Vallabhbhai Patel University of Agriculture and Technology, Meerut (Uttar Pradesh),India, $\left(28^{\circ} 40^{\prime} 07^{\prime \prime} \mathrm{N}\right.$ to $29^{\circ} 28^{\prime} 11^{\prime \prime} \mathrm{N}, 77^{\circ} 28^{\prime} 14^{\prime \prime} \mathrm{E}$ to $77^{\circ} 44$ $18 " E)$ during 2009-2010 to 2011-2012 and was designed as a farmer-managed with a single replicate, repeated over many farmers. Therefore, the experimental design was Randomized Block Design in which farmer as a replicate/ block commencing with kharif in 2009. The climate of the area is semiarid, with an average annual rainfall of $805 \mathrm{~mm} 75$ to $80 \%$ of which is received during July to September), minimum temperature of $4^{\circ} \mathrm{C}$ in January, maximum temperature of 41 to $45^{\circ} \mathrm{C}$ in June, and relative humidity of 67 to $83 \%$ during the year. The soils are generally sandy loam to loam in texture and low to medium in organic matter content. Soil with a bulk density of $1.48 \mathrm{Mg} \mathrm{m}^{-3}, \mathrm{pH}=7.9$, total $\mathrm{C}=8.3 \mathrm{~g} \mathrm{~kg}^{-1}$, total $\mathrm{N}=0.83 \mathrm{~g} \mathrm{~kg}^{-1}$, Olsen $\mathrm{P}=28 \mathrm{mg} \mathrm{kg}{ }^{-1}$, and $\mathrm{K}=128 \mathrm{mg} \mathrm{kg}^{-1}$. Groundwater pumping was the predominant method of irrigation in Western UP. The plots consisted of seven crop establishment treatments and details is given here under,

\footnotetext{
$\mathbf{T}_{1}$-Precision land leveling with wide raised Beds with recommended dose of NPK (PL WB + RNPK)

$\mathrm{T}_{2}$-Traditional land leveling with wide raised Beds with recommended dose of NPK (TL WB + RNPK)

$\mathrm{T}_{3}$-Precision land leveling with narrow raised Beds with recommended dose of NPK (PL NB + RNPK)
} 
$\mathrm{T}_{4}$-Traditional land leveling with narrow raised Beds with recommended dose of NPK (TL NB + RNPK)

$T_{5}$ - Precision land leveling with flat Beds with recommended dose of NPK (PL FB + RNPK)

$\mathrm{T}_{6}$ - Traditional land leveling with flat Beds with recommended dose of NPK (TL FB + RNPK)

$\mathrm{T}_{7}$ Traditional land leveling with flat Beds without NPK (Control/conventional practices) (TL FB $+\mathrm{N}_{0} \mathrm{P}_{0} \mathrm{~K}_{0}$ )

For laser-assisted precision land leveling, the land was first plowed at the optimum moisture level (field capacity) with a harrow/cultivator for pulverization and was leveled using a laserequipped drag scrapper (TrimbleTM, USA) with an automatic hydraulic system attached to a 50-60 HP tractor. Before running the laser leveler, the field was surveyed at $3 \mathrm{~m}$ distance to record the elevation and the elevation points were averaged to know the desired elevation for leveling the field. The average elevation value was entered into the digital control box for controlling the scrapper at the desired elevation point (Naresh et al., 2011) and the tractor was run across the field till the desired elevation was achieved throughout the field. For the traditional land leveling treatment, the field was first ploughed as described above and was leveled using an iron plank attached to a tractor and was dragged across the land surface.

After ploughing with a harrow/cultivator for pulverization of the field at the optimum moisture level, an iron scraper attached to the tractor was moved on the land surface on a visual elevation level. After the cuts and fills of soil, a wooden planker attached to the tractor was moved across the field to smooth the land surface. 'HM10' maize cultivar was seeded in the last week of June and wheat cultivar 'PBW 343' was seeded on $7^{\text {th }}, 9^{\text {th }}$ and $9^{\text {th }}$ Nov. 2009, 2010 and 2011 , respectively. A seed rate of $20 \mathrm{~kg} \mathrm{ha}^{-1}$ for maize and 80 $\mathrm{kg} \mathrm{ha}^{-1}$ was used in treatments where wheat was seeded on beds, and $100 \mathrm{~kg} \mathrm{ha}^{-1}$ was used in the rest of the treatments. The bed furrow width at top was kept at $37 \mathrm{~cm}: 30 \mathrm{~cm}$ having one seed rows for maize and three seed rows for wheat and the depth of the furrow was kept at $15 \mathrm{~cm}$ for narrow beds and furrow width at top was kept at $107 \mathrm{~cm}: 30 \mathrm{~cm}$ having two seed rows for maize and six seed rows for wheat and the depth of the furrow was kept at $12 \mathrm{~cm}$ for wide beds. The plant population was maintained equal in flat as well as raised bed planting.

Irrigation water was applied using polyvinyl chloride pipes of 15 $\mathrm{cm}$ diameter and the amount of water applied to each plot was measured using a water meter (Dasmesh Co., India). The quantity of water applied and the depth of irrigation were computed using the following equations:

Quantity of water applied $(\mathrm{L})=\mathrm{F} \times \mathrm{t}$

Depth of water applied $(\mathrm{mm})=\{L / A / 1000\}$

where $\mathrm{F}$ is flow rate $\left(\mathrm{I} \mathrm{s}^{-1}\right), \mathrm{t}$ is time (s) taken during each irrigation and $A$ is area of the plot $\left(\mathrm{m}^{2}\right)$. Rainfall data was recorded using a rain gauge installed within the meteorological station. The total amount of water (input water) applied was computed as the sum of water received through irrigation and rainfall $(I+R)$. Water productivity $\left(\mathrm{WP}_{\mathrm{I}} \mathrm{+}_{\mathrm{R}}\right)\left(\mathrm{kg}\right.$ grains $\mathrm{m}^{-3}$ ofwater) was computed as follows (Humphreys et al., 2008):

$W P_{1+R}=$ grain yield $\left(\mathrm{kg} \mathrm{ha}^{-1}\right) /\left[\right.$ irrigation water applied $\left(\mathrm{m}^{3}\right)+$ rainfall received by the crop $\left(\mathrm{m}^{3}\right) \mathrm{]ha}^{-1}$.

Soil samples were collected at the start of the experiment from 0 to $15 \mathrm{~cm}$ soil depth using an auger of $5 \mathrm{~cm}$ diameter. Each sample was a composite from three locations within a plot. The freshly collected soil samples were mixed thoroughly, air-dried, crushed to pass through a $2 \mathrm{~mm}$ sieve and stored in sealed plastic jars before analysis. Olsen $\mathrm{P}\left(0.5 \mathrm{M} \mathrm{NaHCO}_{3}\right.$ extractable $)$ and $\mathrm{NH}_{4} \mathrm{OAc}-$ extractable $\mathrm{K}$ were analyzed using the methods described by Page et al. (1982), respectively. Soil organic C was analyzed by Page et al. (1982) method. The samples for determination of soil physical properties (soil aggregates, mean weight diameter of aggregates) were collected at the start of the experiment and after the harvest of each crop. Soil aggregation and mean weight diameters of aggregates were analyzed using the wet-sieving (Yoder, 1936) method. Bulk density was measured to a depth of $20 \mathrm{~cm}$ at intervals of $5 \mathrm{~cm}$ soil depth using the core-ring method and one core per stratus of each plot was collected and the samples were oven-dried for $48 \mathrm{~h}$ at $105^{\circ} \mathrm{C}$, weighed and bulk density calculated according to Blake and Hartge (1986). Soil moisture by gravimetric method (Jalota et al., 1998), soil strength by cone penetrometer. The bulk density were measured at the onset of the experiment and after the 3 years of study.

The plants measured for growth and yield were used for analyzing the $\mathrm{N}, \mathrm{P}$ and $\mathrm{K}$ content in grain and straw. The grain and straw samples were dried at $70^{\circ} \mathrm{C}$ in a hot air oven. The dried samples were ground in a stainless steel Wiley Mill. The $\mathrm{N}$ content in grain and straw were determined by digesting the samples in sulfuric acid $\left(\mathrm{H}_{2} \mathrm{SO}_{4}\right)$, followed by analysis of total $\mathrm{N}$ by Kjeldahl method (Page et al.,1982) using a Kjeltec autoanalyser. The $P$ content (grain and straw) was determined by vanadomolybdophosphoric yellow colour method and the $\mathrm{K}$ content both in grain and straw was analysed in di-acid $\left(\mathrm{HNO}_{3}\right.$ and $\left.\mathrm{HClO}_{4}\right)$ digests by Flame Photometeric method (Page et al., 1982). The uptake of the nutrients was calculated by multi-plying the nutrient content (\%) by respective yield $\left(\mathrm{kg} \cdot \mathrm{ha}^{-1}\right)$ and was divided by 100 to get the uptake values in $\mathrm{kg} \cdot \mathrm{ha}^{-1}$ (Wu et al., 2010). The uptake in grain and straw was summed to get the total uptake of nutrient $\cdot \mathrm{ha}^{-1}$.

\section{Nutrient use efficiency}

The effectiveness of applied nutrients is to establish by this factor. The most important advantage of this index is that it quantifies total economic output from any particular factor/nutrient, relative to its utilization from all resources in the system, including native soil nutrients and nutrients from applied inputs (Dobermann et al., 2002). The following expressions are used for determining these:

\section{Agronomic efficiency $\left(\mathrm{AE}_{\mathrm{N}}\right)$}

$\mathrm{AE}_{\mathrm{N}}=\mathrm{kg}$ grain yield increase per $\mathrm{kg} \mathrm{N}$ applied (often used synonym: $\mathrm{N}$ use efficiency:

$\mathrm{AE}_{\mathrm{N}}=\Delta \mathrm{GY}+\mathrm{N} / \mathrm{FN}$

Where, $\mathrm{GY}_{+\mathrm{N}}$ is the grain yield in a treatment with $\mathrm{N}$ application $\mathrm{kg}$ $\mathrm{ha}^{-1}, \mathrm{GY}_{\mathrm{ON}}$ is the grain yield in a treatment without $\mathrm{N}$ application, and $\mathrm{FN}$ is the amount of fertilizer $\mathrm{N}$ applied, all in the $\mathrm{kg} \mathrm{ha}^{-1}$.

\section{Recovery efficiency of applied nitrogen $\left(R E_{N}\right)$}

$\mathrm{RE}_{\mathrm{N}}=\mathrm{kg} \mathrm{N}$ taken up per $\mathrm{kg} \mathrm{N}$ applied:

$R E_{N}=U N_{+N}-U N_{O N}$

Where, $\mathrm{UN}_{+\mathrm{N}}$ is the total $\mathrm{N}$ uptake measured in above ground biomass at physiological maturity $\left(\mathrm{kg} \mathrm{ha}^{-1}\right)$ in plots that received applied $\mathrm{N}$ at the rate of $\mathrm{FN}\left(\mathrm{kg} \mathrm{ha}^{-1}\right), \mathrm{UN}_{\mathrm{ON}}$ is the total $\mathrm{N}$ uptake without $\mathrm{N}$ addition.

\section{Physiological efficiency of applied nitrogen $\left(\mathrm{PE}_{\mathrm{N}}\right)$}

$\mathrm{PE}_{\mathrm{N}}=\mathrm{kg}$ grain yield increase per $\mathrm{kg}$ fertilizer $\mathrm{N}$ taken up: 
Table 1. Effect of crop establishment on bulk density, water stability of aggregates, clod breaking strength and soil organic carbon (\%) etc. soil properties under maize-wheat cropping system after 3 year's of experimentation in 0 to $15 \mathrm{~cm}$.

\begin{tabular}{|c|c|c|c|c|c|c|c|c|c|}
\hline \multirow[t]{2}{*}{ Treatment } & \multirow{2}{*}{$\begin{array}{l}\text { Bulk density } \\
\quad\left(\mathrm{Mg} \mathrm{m}^{-3}\right)\end{array}$} & \multirow{2}{*}{$\begin{array}{l}\text { Water stable } \\
\text { aggregates } \\
>0.25 \mathrm{~mm}(\%)\end{array}$} & \multirow{2}{*}{$\begin{array}{l}\text { Aggregate } \\
\text { porosity (\%) }\end{array}$} & \multirow{2}{*}{$\begin{array}{l}\text { Clod breaking } \\
\text { strength } \\
\text { (kPa) }\end{array}$} & \multirow{2}{*}{$\begin{array}{l}\text { Soil organic } \\
\text { carbon (\%) }\end{array}$} & \multicolumn{2}{|c|}{$\begin{array}{c}\text { Field capacity } \\
\text { (\% moisture) }\end{array}$} & \multicolumn{2}{|c|}{$\begin{array}{l}\text { Permanent wilting } \\
\text { point (\% moisture) }\end{array}$} \\
\hline & & & & & & $0-5 \mathrm{~cm}$ & $5-20 \mathrm{~cm}$ & $0-5 \mathrm{~cm}$ & $5-20 \mathrm{~cm}$ \\
\hline $\mathrm{T}_{1}$ & 1.44 & 82.8 & 43.2 & 204.8 & 0.63 & 31 & 32 & 13 & 11 \\
\hline $\mathrm{T}_{2}$ & 1.46 & 79.0 & 40.8 & 332.9 & 0.58 & 29 & 30 & 11 & 10 \\
\hline $\mathrm{T}_{3}$ & 1.45 & 81.9 & 42.7 & 235.6 & 0.61 & 30 & 31 & 12 & 11 \\
\hline $\mathrm{T}_{4}$ & 1.48 & 72.9 & 40.2 & 367.5 & 0.55 & 29 & 29 & 11 & 10 \\
\hline $\mathrm{T}_{5}$ & 1.49 & 80.3 & 41.3 & 289.7 & 0.59 & 29 & 30 & 12 & 11 \\
\hline $\mathrm{T}_{6}$ & 1.50 & 66.7 & 39.6 & 418.7 & 0.54 & 28 & 29 & 11 & 10 \\
\hline $\mathrm{T}_{7}$ & 1.55 & 59.1 & 36.2 & 423.8 & 0.52 & 28 & 29 & 11 & 09 \\
\hline CD $5 \%$ & 0.09 & 5.3 & 1.74 & 95.3 & $0.53^{* *}$ & - & - & - & - \\
\hline
\end{tabular}

$P E_{N}=\left(G Y_{+N}-G Y_{O N}\right) /\left(U N_{+N}-U N_{O N}\right)$

Where, $\mathrm{GY}_{+\mathrm{N}}$ is the grain yield in a treatment with $\mathrm{N}$ application $\mathrm{kg} \mathrm{ha}^{-1}, \mathrm{GY}_{\mathrm{ON}}$ is the grain yield in a treatment without $\mathrm{N}$ application, $\mathrm{UN}_{+\mathrm{N}}$ are the total $\mathrm{N}$ uptake in a treatment with $\mathrm{N}$ application $\mathrm{kg} \mathrm{ha}^{-1}, \mathrm{UN}_{\mathrm{N}}$ is the total $\mathrm{N}$ uptake in a treatment without $\mathrm{N}$ application.

\section{Partial factor productivity $\left(\right.$ PFP $\left._{N}\right)$}

$\mathrm{PFP}_{\mathrm{N}}=\mathrm{kg}$ grain per $\mathrm{kg} \mathrm{N}$ applied:

$\mathrm{PFP}_{\mathrm{N}}=\mathrm{GY}_{+\mathrm{N}} / \mathrm{FN}$

Where, $G Y_{+N}$ is the grain yield in $\mathrm{kg} \mathrm{ha}^{-1}$ and $\mathrm{FN}$ is the amount of fertilizer $\mathrm{N}$ applied in $\mathrm{kg} \mathrm{ha}^{-1}$.

\section{RESULTS AND DISCUSSION}

\section{Soil properties}

Tillage significantly affected the soil significant variations after three crop cycles the soil physical properties in bulk density, water stable aggregates, aggregate porosity, clod breaking strength, organic carbon, available $\mathrm{N}, \mathrm{P}$ and $\mathrm{K}$ were recorded due to different treatments (Table 1). The bulk density did not varied significantly due to land leveling however, planting techniques had significant influence and it was significantly reduced under raised bed planting compared to flat sowing irrespective of the land leveling practice. This was attributed mainly due to more pore spaces created in the beds through modified land configuration by accumulations the topsoil. Bed planting provides natural opportunity to reduce compaction by confining traffic to the furrow bottoms (Govaerts et al., 2006). The soil organic carbon content in top soil $(0$ to $15 \mathrm{~cm})$ was increased significantly due to raised bed planting compared to flat sowing planting mostly because of localized deposition of more fertile top soil on beds under altered land configuration than flat planting. Available nitrogen, phosphorus and potassium status of soil analyzed after harvest of third wheat crop showed significant variation due to different treatments (Table 2). Maximum available $\mathrm{N}, \mathrm{P}$ and $\mathrm{K}$ content in soil was recorded under PLWB being at par with TLWB but were significantly superior to all other treatments. Further, flat planting either on precision or traditional leveling were at par with each other at similar fertility levels.

\section{Nutrient uptake}

Total (grain + straw) uptake of nutrients $(\mathrm{N}, \mathrm{P}, \mathrm{K})$ analyzed at crop maturity varied significantly due to land leveling and crop establishment techniques. Maximum uptake of total $\mathrm{N}$ was recorded with PLWB which was significantly higher over all other treatments (Figure 1). Similar to nitrogen, maximum uptake of total $\mathrm{P}$ was also recorded in PLWB which was at par to PLNB but it was significantly higher over rest of the treatments (Figure 1). The total K uptake by the crop though at par, under precision land leveling irrespective of the planting technique (that is, PLWB, PLNB and PLFB) but significantly higher over rest of the treatments (Figure 1). The higher amount of uptake of nutrients under precision leveling and raised bed planting techniques was associated with higher bio-mass accumulation under these treatments, which led to higher amount of uptake of these nutrients. The higher nutrient uptake in 
Table 2. Effect of crop establishment on available $\mathrm{N}$, available $P$ and available $\mathrm{K}(\mathrm{kg} / \mathrm{ha})$ under maizewheat cropping system after 3 year's of experimentation in $0-15 \mathrm{~cm}$.

\begin{tabular}{lccc}
\hline Treatment & Available N (kg/ha) & Available P $\mathbf{( k g / h a )}$ & Available $\mathbf{K}$ (kg/ha) \\
\hline $\mathrm{T}_{1}$ & 261.5 & 13.7 & 247.0 \\
$\mathrm{~T}_{2}$ & 250.1 & 12.1 & 241.8 \\
$\mathrm{~T}_{3}$ & 259.3 & 13.5 & 245.9 \\
$\mathrm{~T}_{4}$ & 249.0 & 11.9 & 240.7 \\
$\mathrm{~T}_{5}$ & 258.1 & 13.2 & 244.3 \\
$\mathrm{~T}_{6}$ & 243.4 & 11.8 & 240.2 \\
$\mathrm{~T}_{7}$ & 139.5 & 8.6 & 232.5 \\
$\mathrm{CD} 5 \%$ & 6.7 & 0.40 & 2.15 \\
\hline
\end{tabular}

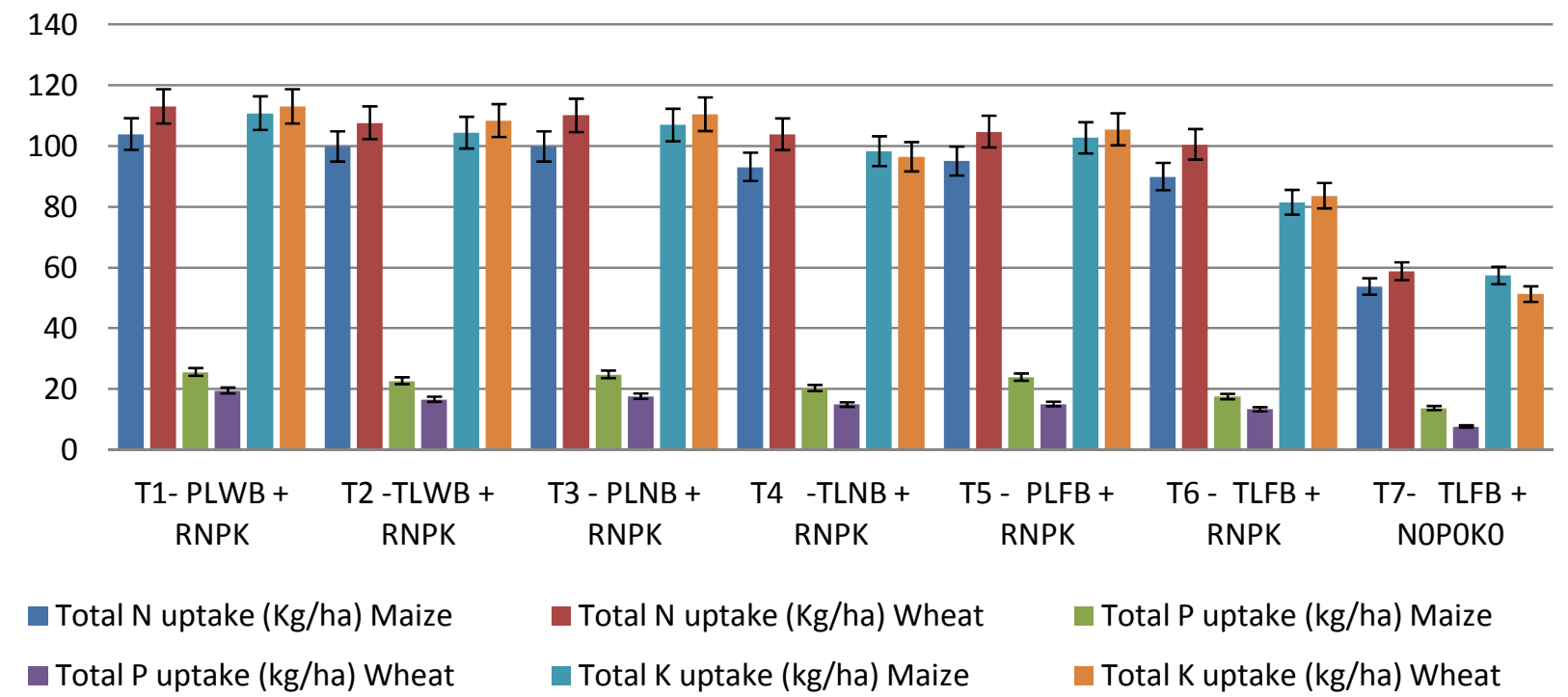

Figure 1. Effect of various tillage and establishment techniques on total $\mathrm{N}, \mathrm{P}$ and $\mathrm{K}$ uptake in maize wheat rotation means at $\mathrm{P}=$ 0.05 .

Precision leveling with raised beds is mainly due to less leaching loss of nutrients and availability of sufficient moisture for mineralization of native as well as applied nutrients. The higher uptake efficiency of nutrients depends on a myriod of factors including nutrient availability due to favourable soil biota under precision leveling with raised beds compared to precision leveling with flat beds. These findings are in agreement with Jat et al. (2006) and Walker et al. (2003).

\section{Nutrient use efficiency}

The agronomic as well as recovery efficiency of applied nutrients was in general higher in precision leveling permanent wide beds. Effeciencies tended to be lower in traditional leveling flat beds (TLFB) than precision leveled wide or narrow raised beds treatments. Effeciencies on raised beds consistently increased but the differences between precision leveled and traditional leveled permanent raised beds were not always significant for the maize- wheat crop cycles with the same level of nutrient application (Figure 2).

\section{Agronomic efficiency (AE)}

The agronomic efficiency (AE) of applied nutrients as unit grain production per unit of applied nutrients after deducting the soil supplying capacity was calculated for all the treatments. The AE of applied $\mathrm{N}$ was significantly higher under precision leveling with wide raised bed treatment compared to other treatments. The efficiency of the nutrient under PLWB + RNPK, and PLNB + RNPK was at par but significantly superior to PLFB + RNPK. The efficiency under PLFB + RNPK, TLNB + NPK and TLFB + RNPK were at par but significantly inferior to TLWP + RNPK. While traditional leveling without NPK 


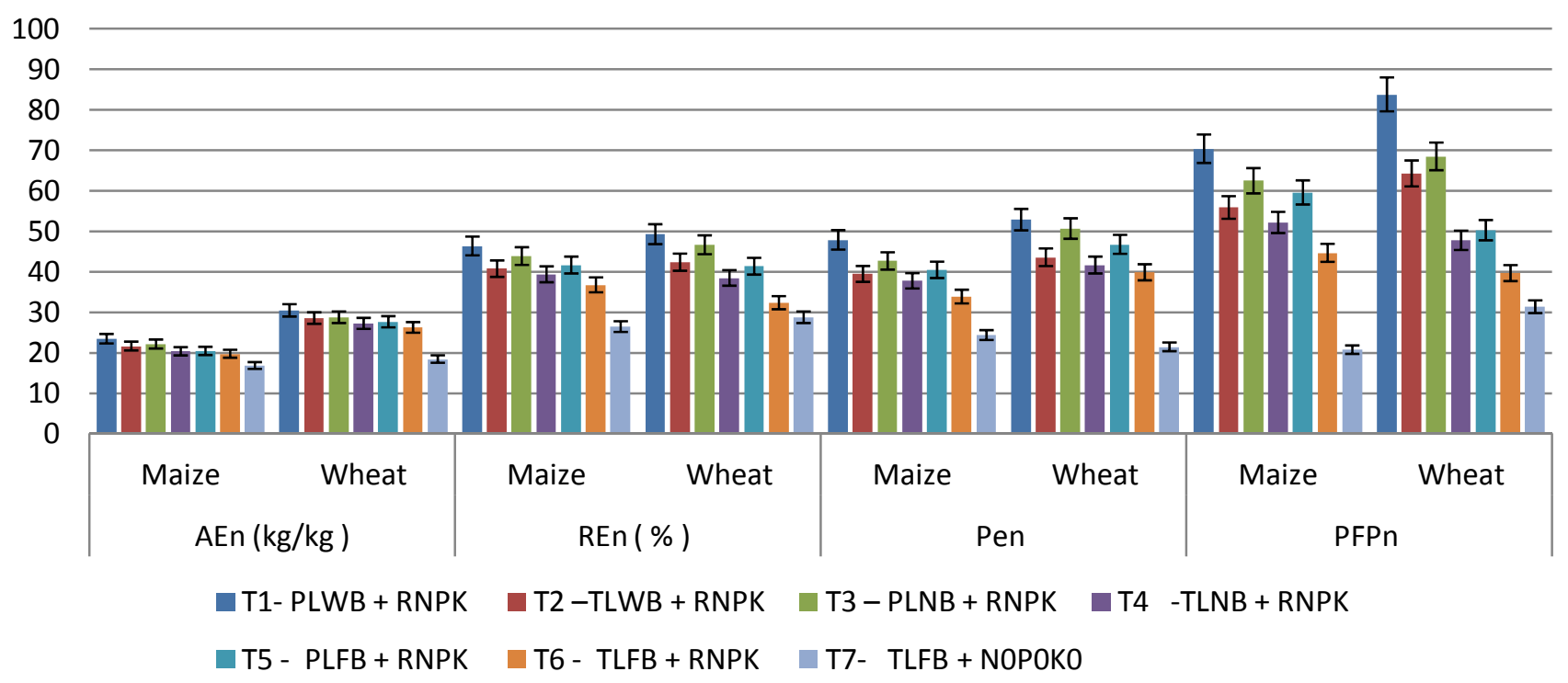

Figure 2. Estimates of $N$ use efficiency that is, Agronomic Efficiency of $N\left(A E_{n}\right)$, Recovery Efficiency of $N\left(R E_{n}\right), P h y s i o l o g i c a l$ Efficiency of $\mathrm{N}(\mathrm{Pen})$ and Partial Factor Productivity of $\mathrm{N}\left(\mathrm{PFP}_{\mathrm{n}}\right)$ in maize - wheat rotation means at $\mathrm{P}=0.05$.

(TLFB $+\mathrm{N}_{0} \mathrm{P}_{0} \mathrm{~K}_{0}$ ) had significantly lower $\mathrm{AE}$ than all other treatments (Figure 2).

\section{Recovery efficiency (RE)}

Data on true recovery efficiency (REnt) shows that in maize the values ranged from 26.4 to $46.3 \%$, while in wheat these ranged from 28.7 to $49.7 \%$. Maize-wheat cropping system is a new rising system for the backbone of food security in India and the values of apparent recovery efficiency of $\mathrm{N}$ (REn) of maize and wheat experiment are in Table 4. Data in Table 4 clearly show that the values of all the terms associated with $\mathrm{N}$ use efficiency (NiUE) declined in all traditional leveling plots. At $\mathrm{N}$ levels similar to those in Figure 2, values of all NiUE terms in maize were lower in compared to the wheat. On the other hand, values of all terms of NiUE showing that in experiment $\mathrm{N}$ is more efficiently utilized for wheat than maize. Thus in maize there is considerable scope to increase NiUE. Precision leveling irrespective of planting technique exerted significant effect on RE-N. The RE-N under PLWB+RNPK was significantly higher over all other treatments. Further, the recovery efficiency under TLLFB+RNPK also improved significantly compared to $T L N B+R N P K$, TLFB+RNPK and TLFB $+\mathrm{N}_{0} \mathrm{P}_{0} \mathrm{~K}_{0}$ (Figure 2).

\section{Water application and water productivity}

The input water application includes the irrigation water applied and the rain water during the maize-wheat season of 2009 to 2010 to 2011 to 2012. The water application in maize-wheat system was remarkably lower with permanent wide and narrow beds compared to other practices (Tables 3 and 4). The higher irrigation water application in maize- wheat system under traditional leveling treatments as compared to precision leveled plots. The precision leveled plots savings in water use in raised beds with recommended dose of NPK were 11.5 to $20.5 \%$ in maize and 14.1 to $26.7 \%$ in wheat as compared to traditional leveled flat beds with recommended dose of fertilizer treatment $\left(T_{6}\right)$. Water productivity under permanent beds was higher as compared to other tillage and crop establishment techniques and lowest system water productivity was recorded with traditional leveled flat beds. Bhushan et al. (2007) revealed that the saving in irrigation water with raised bed planting technique was more under traditional leveling as in this technique water moves in furrows only. Laser assisted precision land leveling can reduce evaporation and percolation losses from wheat by enabling faster irrigation times and by eliminating depressions and therefore ponding of water in depressions.

\section{Grain yields}

The crop yield data from 2009-2012 (Table 1) showed that the higher grain yields of maize occurred in precision land leveling permanent wide beds with recommended dose of NPK. Yields on raised beds consistently increased from 1 to 3 year in laser leveling with recommended NPK, but the differences between laser leveling permanent wide raised beds and permanent narrow raised beds were not always significant for the three maize- wheat crop cycles. 
Table 3. Water productivity and profitability of maize and wheat rotation under various tillage and establishment techniques.

\begin{tabular}{|c|c|c|c|c|c|c|c|c|c|c|c|c|}
\hline \multirow{3}{*}{ Crop establishment } & \multicolumn{6}{|c|}{ Water productivity ( $\mathrm{kg}$ yield $\mathrm{m}^{-3}$ water) } & \multicolumn{6}{|c|}{ Net profit ( Rs ha ${ }^{-1}$ ) } \\
\hline & \multicolumn{3}{|c|}{ Maize } & \multicolumn{3}{|c|}{ Wheat } & \multicolumn{3}{|c|}{ Maize } & \multicolumn{3}{|c|}{ Wheat } \\
\hline & 2009 & 2010 & 2011 & 2009-2010 & $2010-2011$ & 2011-2012 & 2009 & 2010 & 2011 & 2009-2010 & $2010-2011$ & 2011-2012 \\
\hline$T_{1}-P L W B+R N P K$ & 1.31 & 1.42 & 1.53 & 1.75 & 1.82 & 2.06 & 23580 & 24680 & 25375 & 23585 & 23875 & 24560 \\
\hline $\mathrm{T}_{2}-\mathrm{TLWB}+\mathrm{RNPK}$ & 1.16 & 1.17 & 1.17 & 1.54 & 1.52 & 1.50 & 22320 & 22495 & 23310 & 21525 & 21650 & 21985 \\
\hline $\mathrm{T}_{3}-\mathrm{PLNB}+\mathrm{RNPK}$ & 1.24 & 1.33 & 1.39 & 1.57 & 1.69 & 1.78 & 22765 & 23570 & 24125 & 22350 & 22790 & 23275 \\
\hline $\mathrm{T}_{4}-\mathrm{TLNB}+\mathrm{RNPK}$ & 1.10 & 1.11 & 1.12 & 1.41 & 1.40 & 1.36 & 21550 & 22200 & 23050 & 21300 & 21435 & 21525 \\
\hline$T_{5}-P L F B+R N P K$ & 1.10 & 1.15 & 1.22 & 1.40 & 1.45 & 1.52 & 20910 & 21375 & 21890 & 21750 & 21975 & 22430 \\
\hline $\mathrm{T}_{6}-\mathrm{TLFB}+\mathrm{RNPK}$ & 1.01 & 1.00 & 1.01 & 1.25 & 1.19 & 1.19 & 19500 & 19760 & 20300 & 20050 & 19610 & 19250 \\
\hline $\mathrm{T}_{7-} \quad \mathrm{TLFB}+\mathrm{N}_{0} \mathrm{P}_{0} \mathrm{~K}_{0}$ & 0.60 & 0.52 & 0.49 & 0.76 & 0.70 & 0.59 & 12650 & 11275 & 10725 & 11950 & 10990 & 09725 \\
\hline
\end{tabular}

Table 4. Maize and wheat water application $\left(\mathrm{mm} \mathrm{ha}^{-1}\right)$ and crop yield $\left(\mathrm{t} \mathrm{ha}^{-1}\right)$ in laser-leveled and traditionally leveled field under different tillage and crop establishment methods.

\begin{tabular}{|c|c|c|c|c|c|c|c|c|c|c|c|c|}
\hline \multirow{3}{*}{ Crop establishment } & \multicolumn{6}{|c|}{ Maize } & \multicolumn{6}{|c|}{ Wheat } \\
\hline & \multicolumn{2}{|c|}{2009} & \multicolumn{2}{|c|}{2010} & \multicolumn{2}{|c|}{2011} & \multicolumn{2}{|c|}{$2009-2010$} & \multicolumn{2}{|c|}{$2010-2011$} & \multicolumn{2}{|c|}{$2011-2012$} \\
\hline & Water & Yield & Water & Yield & Water & Yield & Water & Yield & Water & Yield & Water & Yield \\
\hline $\mathrm{T}_{1}-\mathrm{PLWB}+\mathrm{RNPK}$ & 325 & 4.25 & 310 & 4.40 & 300 & 4.60 & 295 & 5.15 & 285 & 5.20 & 260 & 5.35 \\
\hline $\mathrm{T}_{2}-\mathrm{TLWB}+\mathrm{RNPK}$ & 345 & 4.00 & 350 & 4.05 & 360 & 4.20 & 305 & 4.70 & 310 & 4.72 & 320 & 4.80 \\
\hline $\mathrm{T}_{3}-\mathrm{PLNB}+\mathrm{RNPK}$ & 330 & 4.10 & 320 & 4.25 & 312 & 4.35 & 315 & 4.95 & 295 & 5.00 & 290 & 5.15 \\
\hline $\mathrm{T}_{4}-\mathrm{TLNB}+\mathrm{RNPK}$ & 355 & 3.90 & 360 & 4.00 & 370 & 4.15 & 330 & 4.65 & 335 & 4.68 & 345 & 4.70 \\
\hline $\mathrm{T}_{5}-\mathrm{PLFB}+\mathrm{RNPK}$ & 360 & 3.95 & 350 & 4.02 & 345 & 4.20 & 340 & 4.75 & 330 & 4.77 & 320 & 4.85 \\
\hline $\mathrm{T}_{6}-\mathrm{TLFB}+\mathrm{RNPK}$ & 370 & 3.75 & 375 & 3.80 & 385 & 3.90 & 355 & 4.45 & 370 & 4.42 & 375 & 4.45 \\
\hline $\begin{array}{l}\mathrm{T}_{7-} \quad \text { TLFB }+\mathrm{N}_{0} \mathrm{P}_{0} \mathrm{~K}_{0} \\
\text { C D at } 5 \%\end{array}$ & $\begin{array}{c}385 \\
- \\
\end{array}$ & $\begin{array}{l}2.30 \\
0.21 \\
\end{array}$ & $\begin{array}{c}390 \\
- \\
\end{array}$ & $\begin{array}{l}2.05 \\
0.29 \\
\end{array}$ & $\begin{array}{c}397 \\
- \\
\end{array}$ & $\begin{array}{l}1.95 \\
0.37 \\
\end{array}$ & $\begin{array}{c}360 \\
- \\
\end{array}$ & $\begin{array}{l}2.75 \\
0.24 \\
\end{array}$ & $\begin{array}{c}365 \\
- \\
\end{array}$ & $\begin{array}{l}2.55 \\
0.23 \\
\end{array}$ & $\begin{array}{c}380 \\
- \\
\end{array}$ & $\begin{array}{ll} & 2.25 \\
0.31 & \\
\end{array}$ \\
\hline
\end{tabular}

Precision leveling with residue retain increase the yield by 8.5 to $10.9 \%$ in maize and 10.1 to $13.1 \%$ in wheat as compared to conventional seeding. This is an extremely important finding in relation to practical management of such systems by farmers. Data pertaining to crop yield parameters of wheat (Table 4) showed significant variation due to land leveling and planting techniques during the study years. The yield level, in general, under all the treatments was little higher during year 3 compared to year 1 and 2. This was attributed mainly due to more sunshine hours cross the season in year 3 compared to year 1 and 2. Also, the minimum temperature during flowering season was higher during year 1 and 2 compared to year 3 which limits the reproductive period and responsible for lower yields of wheat. Grain yield of wheat varied significantly due to laser leveling permanent wide raised beds with recommended dose of NPK (PLWB +RNPK) techniques and significantly higher yield levels of $5.15,5.20$ and $5.35 \mathrm{t} \cdot \mathrm{ha}^{-1}$ were recorded under (PLWB+ RNPK) during year 1, 2 and 3 , respectively compared to other treatments. The increase in grain yield with (PLWB+ RNPK) was $8.3,8.7$ and $9.3 \%$ during year 1,2 and 3 , respectively whereas the corresponding increase under flat bed planting was recorded at $6.3,7.3$ and $8.2 \%$. The yield under permanent wide raised beds traditional land leveling with recommended 
dose of NPK (TLWB+RNPK) and and laser leveling permanent narrow raised beds with recommended dose of NPK (PLNB+RNPK) did not varied significantly during the years because productive tillers, length of spike and number of grains/spike are almost same. Further, with the same level of land leveling and different levels of planting techniques, the wheat yield varied remarkably. Raised bed showed 5.9, 6.4 and $7.6 \%$ yield advantage over flat bed planting under precision leveling during year 1,2 and 3 , respectively whereas, the corresponding increase in yield under traditional leveling was recorded at $4.7,5.9$ and $6.3 \%$. It showed that the raised bed planting technique is more advantageous under precisely leveled fields. Significantly higher yield of maize-wheat was recorded with precision land leveling as it takes care of maintaining near homogeneity by way of cut and fill and also tillage (Hassan et al., 2005; Borrell and Garside 2004). These findings are in agreement with Gupta and Sayre (2007); Rajput and Patel (2004) and Naresh et al. (2011a, b) who summarized the finding of multilocation trails across IGP and reported higher yield of wheat with raised beds compared to flat sowing.

\section{Profitability}

The net income through maize was higher with precision leveling permanent raised beds with recommended dose of NPK followed by $P L N B+R N P K>T L W B+R N P K>T L N B+R N P K \quad$ and $P L F B+R N P K$ and the lowest being recorded with $T L F B+N_{0} P_{0} K_{0}$ (Table 3). The lower net income with the conventional tillage was due to the cost on preparing the field. Profitability of wheat was remarkably higher with precision leveling permanent wide raised beds practices due to higher productivity and less cost of production compared to conventional tillage practices $\left(T_{7}\right)$ treatment. Over the past decade, researchers in association with farmers and entrepreneurs have been trying to overcome the problems of depleting water resources, diminishing input use efficiency, declining farm profitability, and deteriorating soil health by developing, evaluating and refining conservation and precision agriculture-based resource-conserving technologies for the maize-wheat rotation in the western U. P. Precision land leveling and permanent beds planting with recommended dose of NPK have a tremendous potential for improving the use efficiency of natural as well as externally applied resources. Many new opportunities based on precision land leveling and permanent beds planting with recommended dose of NPK have appeared to give stimulus to the productivity through a more sustainable pace of natural resource use in maize-wheat based cropping system. Taken together, these practices can rise productivity, cut costs, save water and soils, reduce use of external inputs, foster greater agro-ecosystem diversity and generate employment. Lignified residual straw and roots added more organic matter and nutrients into the soils under permanent raised beds, resulting in increased nutrient uptake by the crops. Crop yields on beds with precision land leveling rose by about $11.8 \%$ for maize and $13.5 \%$ for wheat over 3 -year cycle compared with conventional tillage on the flat beds.

\section{FUTURE THRUST OF RESEARCH}

(i) Conservation tillage practices like precision land leveling and permanent bed planting utilizes more judiciously the plant available water than the conventional tillage when the other factors are similar.

(ii) Precision-Conservation Agriculture (PCA) based crop management solutions seem to be promising options to sustain the maize- wheat systems of South Asia on a long-term basis.

\section{Conflict of Interests}

The author(s) have not declared any conflict of interests.

Abbreviations: PLWB, Precision land leveling with wide raised Beds (Tops of the beds $107 \mathrm{~cm}$ and Furrow width $30 \mathrm{~cm}$ and $12 \mathrm{~cm}$ depth); TLWB, Traditional land leveling with wide raised Beds (Tops of the beds $107 \mathrm{~cm}$ and Furrow width 30 and $12 \mathrm{~cm}$ depth); PLNB, Precision land leveling with narrow raised Beds (Tops of the beds $37 \mathrm{~cm}$ and Furrow width 30 and $15 \mathrm{~cm}$ depth); RNPK, recommended dose of NPK (120:60:40 kg/ha); PLFB, Precision land leveling with flat Beds.

\section{ACKNOWLEDGEMENTS}

The authors are grateful to the Director of Research of the Sardar Vallabhbhai Patel University of Agriculture and Technology, Meerut, U. P. India for providing facilities and encouragement. Also, Uttar Pradesh Council of Agricultural Research, Lucknow deserve thanks for their financial assistance under the project "Resource Conservation Technologies for Sustainable Development of Agriculture".

\section{REFERENCES}

Blake GR, Hartge KH (1986). Bulk density. In: Klute A,Campbell GS,Jackson RD,Mortland MM, Nielsen DR (Eds.) Methods of Soil Analysis,Part I.ASA and SSSA, Madison,WI, USA, pp. 363-375.

Bhushan L,Ladha JK,Gupta RK,Singh S,Padre AT, Saharawat YS,Gathala M, Pathak H (2007). Saving of Water and Labour in a Rice-Wheat System with No-Tillage and Direct Seeding Technologies. Agron. J. 99(5):1288-1296. http://dx.doi.org/10.2134/agronj2006.0227

Borrell A,Garside A (2005). Early work on permanent raised beds in tropical and subtropical Australia focusing on the development of a rice-based cropping system. Evaluation and performance of 
permanent raised bed cropping systems in Asia, Australia and Mexico edited by C.H. Roth, R.A. Fischer and C.A. Meisner. ACIAR Proceedings 121:120-128.

Doberman A, Witt C, Dawe D, Abdulrachman S, Gines HC, Nagarajan R, Satawatananont S, Son TT, Tan PS, Wang GH, Chien NV, Thoa VTK, Phung CV, Stalin P, Muthukrishnan P, Ravi V, Babu M, Chatuporn S, Sookthongsa J, Sun Q,Fu R, Simbahan GC, Adviento

MAA (2002). Site- specific nutrient management for intensive rice cropping systems in Asia. Field Crops Res. 74:37-66.

Gupta R, Sayre KD (2007). Conservation Agriculture in South Asia. J. Agric. Sci. 145:207-214. http://dx.doi.org/10.1017/S0021859607006910

Govaerts B, Sayre KD, Ceballos-RamirezJ, Luna-Guido ML, LimonOrtega A, Deckers J, Den-dooven L (2006). Conventionally Tilled and Permanent Raised Beds with Different Crop Residue Management: Effect on Soil C and N Dynamics. Plant. Soil 280:143-155. http://dx.doi.org/10.1007/s11104-005-2854-7

Hassan I, Hussain Z,Akbar G (2005). Effect of permanent raised beds on water productivity for irrigated maize -wheat cropping system. Evaluation and performance of permanent raised bed cropping systems in Asia, Australia and Mexico edited by C.H. Roth, R.A. Fischer and C.A. Meisner ACIAR Proceedings 121:59-65.

Humphreys E, Kukal SS, Amanpreet-Kaur, Thaman S, Yadav S, Yadvinder-Singh, Balwinder-Singh, Timsina J, Dhillon SS, Prashar A, Smith DJ (2008). Permanent beds for rice-wheat in Punjab, India. Part 2:water balance and soil water dynamics. In 'Permanent beds and rice-residue management for rice-wheat systems in the IndoGangetic Plain'. Eds E. Humphreys and C.H. Roth.These Proceedings.

Jalota SK, Khera R, Ghuman BS (1998). Methods in Soil Physics, Narosa Publishing House, New Delhi pp. 65-67.

Jat ML, Chandana P, Sharma SK, Gill MA, Gupta RK (2006). Laser Land Leveling-A Precursor Technology for Resource Conservation. Rice-Wheat Consortium Technical Bulletin Series 7, Rice-Wheat Consortium for the Indo-Gangetic Plains, New Delhi.

Jat ML, Gupta R, Saharawat YS, Khosla R (2011). Layering Precision Land Leveling and Furrow Irrigated Raised Bed Planting: Productivity and Input Use Efficiency of Irrigated Bread Wheat in Indo-Gangetic Plains. Am. J. Plant Sci. http://dx.doi.org/10.4236/ajps.2011.24069

Ladha JK, Pathak H, Timothy J, Krupnik J, Chris van K (2013). Efficiency of fertilizer nitrogen in cereal production: Retrospects and Prospects. Adv. Agro. 87:85-156. http://dx.doi.org/10.1016/S00652113(05)87003-8

Malik RK, Yadav A, Gill GS, Sardana P, Gupta RK, Piggin C (2004). Evolution and acceleration of no-till farming in rice-wheat system of the Indo-Gangetic Plains. 4th International Crop Science Congress held in Brisbane, Australia from September 26 to October pp. 1-73.

Naresh RK, Gupta RK, Satya P, Kumar A, Singh M, Misra AK (2011a). Permanent beds and rice-residue management for rice-wheat systems in the North West India. Int. J. Agric. Sci. 7(2):429-439.
Naresh RK, Gupta RK, Kumar Ashok, Satya P, Tomar SS, Singh A, Rathi RC, Misra AK, Singh M (2011b). Impact of laser leveler for enhancing water productivity in Western Uttar Pradesh. Int. J. Agric. Eng. 4(2):133-147.

Naresh RK, Singh SP, Misra AK, Tomar SS, Kumar P, Kumar V, Kumar $S$ (2014). Evaluation of the laser leveled land leveling technology on crop yield and water use productivity in western Uttar Pradesh. Afr. J. Agric. Res. 9(4):473-478.

http://dx.doi.org/10.5897/AJAR12.1741

Page AL, Miller RH, Keeney DR (Eds.) (1982). Methods of soil analysis.Part 2.Chemical and microbiological properties. 2nd ed. Agron. Monogr. 9, ASA, CSSA, and SSSA, Madison, WI.

Rajput TBS, Patel N (2004). Effect of Land Leveling on Irrigation Efficiencies and Wheat Yield. J. Soil Water Conser. 3:86-96.

Ram H, Singh Y, Timsina J, HumphreysE, Dhillion SS, Kumar K, Kaler DS (2005). Evaluation and performance of permanent raised bed cropping systems in Asia, Australia and Mexico', ed. By Roth C.H., Fischer R.A. and Meisner C.A. ACIAR Proceedings 121:1-58.

Sayre KD,Hobbs PR (2004). The raised-bed system of cultivation for irrigated production conditions. in 'Sustainable agriculture and the international rice-wheat system',ed. By Sustainable Agriculture and the Rice-Wheat System. pp. 337-355.

Walker TW, Kingery WL, Street Joe E, Lox MS, Oldham JL, Gerard PD,Aan FX (2003). Rice Yield and Soil Chemical Properties as Affected by Precision Land Leveling in Alluvial Soils. Agron. J. 95:1483-1488 http://dx.doi.org/10.2134/agronj2003.1483

Yoder RE (1936). A direct method of aggregate analysis and study of the physical nature of erosion losses. J. Am. Soc. Agron. 28:337351. http://dx.doi.org/10.2134/agronj1936.00021962002800050001x

Wu C, Lu L, Yang X, Feng Y, Wei Y, Hao H, Stoffella PJ, He Z (2010). Uptake, translocation, and remobilization of zinc absorbed at different growth stages by rice genotypes of different $\mathrm{Zn}$ densities. J. Agric. Food Chem. 58:6767-6773 http://dx.doi.org/10.1021/jf100017e PMid:20481473 